\section{NSF returns to favour with biggest increase}

Christmas has come late for the National Science Foundation (NSF), for which the Clinton administration is proposing a budget increase of 10 per cent, to $\$ 3.8$ billion, next year (see right) - more than any other major government science agency. A slightly lower percentage is allocated to the agency's education activities, so NSF's research directorates will receive, if the Congress implements the proposal, an unprecedented 12 per cent increase.

Neal Lane, director of NSF, says he is uncertain what led the administration finally to accept the case - long put by advocates of the agency - that its wide portfolio of science support deserves to benefit from the groundswell of public support for more biomedical research. "I don't think I could pick out what made the difference. But the strong and consistent support of Harold Varmus [director of NIH] has been very important."

The agency plans to use the money to increase the size and duration of its grants, while holding the success rate of grant applications steady at the current rate of 33 per cent. "We've been trying to push in this direction for a long time," says Lane. "But recently we'd lost a little ground." The agency plans to increase the average annual value of a grant from $\$ 80,000$ in 1997 to $\$ 90,000$ in 1999 , and to stretch its average duration from 2.3 to 2.7 years.

In keeping with the administration's commitment to research on faster Internet links, the Computer and Information Science and Engineering (CISE) directorate fares best in the proposal, with an increase in funding of 16.5 per cent to $\$ 330$ million. The other research directorates get about 11 per cent rises each, and the new Plant Genome Initiative is funded at this year's level of \$40 million. ColinMacilwain

\title{
Biomedical research shines in Clinton budget bonanza
}

[WASHINGTON] President Bill Clinton this week promised record increases in funding for the National Institutes of Health (NIH) and the National Science Foundation (NSF) in a budget that delighted science advocates and confounded widespread expectations of tough times ahead for US researchers.

The Clinton administration is proposing increases of 8.4 per cent, or $\$ 1.15$ billion, at NIH for the 1999 financial year, which begins on 1 October. An unprecedented 12 per cent increase would be made in research funding at the NSF, which supports most nonbiomedical research at US universities. Other agencies with strong basic research interests also fared well, as the administration dropped the emphasis on technology support that had characterized its previous five budgets.

Clinton had promised "the greatest increases in history" for NIH and NSF during his State of the Union address on 26 January, which was watched by a record television audience, largely because of recent accounts of his alleged marital infidelity. Harold Varmus, director of the NIH, was guest of honour at the address, and strategically seated next to the president's wife Hillary.

New projections published by the administration would increase the NIH budget by half to more than $\$ 20$ billion by 2003 . Other non-defence research programmes would also prosper thanks to a '21st Century Research Fund', worth $\$ 171$ billion over five years, announced by Clinton.

According to White House officials, the fund has no special legal status. But \$25 billion is expected to come from new taxes on cigarettes which the Congress may enact as part of a 'tobacco agreement' later this year.

Announcing the science and technology budget proposal, Vice-President Al Gore described the five-year plan as "the largest commitment to key civilian research in the

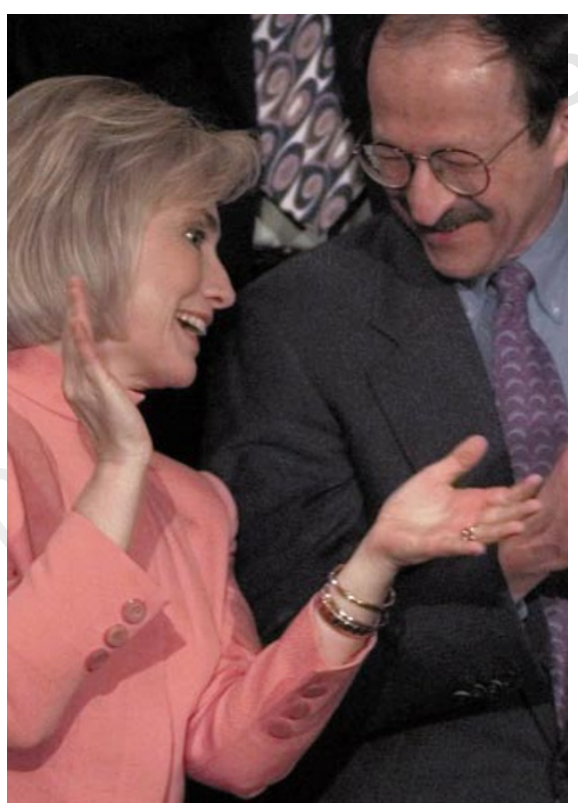

Good times ahead: NIH director Harold Varmus and Hillary Clinton applaud her husband.

history of the United States". He added that "more and more we find that science and society are interconnected", and predicted that science would shortly cross "important crossroads", including the complete sequencing of the human genome and the creation of "the first preventative cancer medicines".

Varmus described the increase for the $\mathrm{NIH}$ as being "of historic proportions". He added: "It is double what any president has ever asked for, and more than the Congress has ever appropriated."

Neal Lane, director of the NSF, said that the increase at his agency "set the stage for a new century of progress in knowledge and discovery. It is a great time to be a scientist, and even a good time to be a science bureaucrat."

The budget proposal would increase total

\section{NASA cuts Earth observation, boosts 'gravitational biology'}

Space agency chief Daniel Goldin, who has promised the White House that he can do more with less, will not be sharing in the federal research spending spree. NASA's 1999 budget request drops slightly from this year's approved level, to $\$ 13.46$ billion.

Nevertheless, Goldin says, "for what we have on our plate today, we have adequate resources", and all major initiatives are fully funded. Space science - which includes astronomy, solar-terrestrial studies, and planetary exploration remains about level with last year's allocation, at $\$ 2$ billion.
The Discovery low-cost planetary programme, which has added two missions to its launch queue, gets a 65 per cent boost. Major development efforts, such as the Space Infrared Telescope Facility (SIRTF), the Origins programme and Mars exploration, stay on track, and the agency will begin work on a Europa orbiter to launch in 2003 as its first low-cost outer planets mission.

The Earth Observing System (EOS) of satellites takes a cut from \$704 million to $\$ 659$ million. But NASA will increase spending on smaller, more focused 'Earth probes. While funding for microgravity research stays flat, gravitational biology and biomedical research each increase by about 25 per cent, and funding for space station research equipment jumps dramatically, from \$221 million to \$374 million.

One possible setback for space scientists has emerged. Last year, Congress ordered NASA not to borrow money from other parts of the agency to pay for an overrun in space station funding. Goldin now says that the agency wants to transfer $\$ 50$ million in unspent funds from each of the Earth science and space science accounts to help solve the station's problem.

Tony Reichhardt 
basic research paid for by the government by 8 per cent, or $\$ 1.2$ billion, to $\$ 17$ billion, and applied research by 5 per cent, or $\$ 850$ million, to $\$ 16.5$ billion. Total federally funded research and development would grow by 3 per cent to $\$ 78$ billion.

The emphasis on basic research echoes the views of leading Republicans in Congress, and contrasts with Clinton's previous emphasis on technology programmes. But Jack Gibbons, the president's science adviser, denies that the administration has been bounced by the Republicans into backing basic research. "We're delighted that there are calls for increased research and development from Capitol Hill," Gibbons says. "It would be fruitless and unproductive to argue about who came first."

The administration proposes to spend priorities, including education and the environment, without cutting other spending or consuming the $\$ 9.5$ billion budget surplus projected for 1999. The budget avoids breaching the spending limits set in last year's balanced budget agreement by proposing that extra money should be diverted to research through a tobacco settlement.

Colin Macilwain the money on research and other investment

Global warming is bright spot for Energy

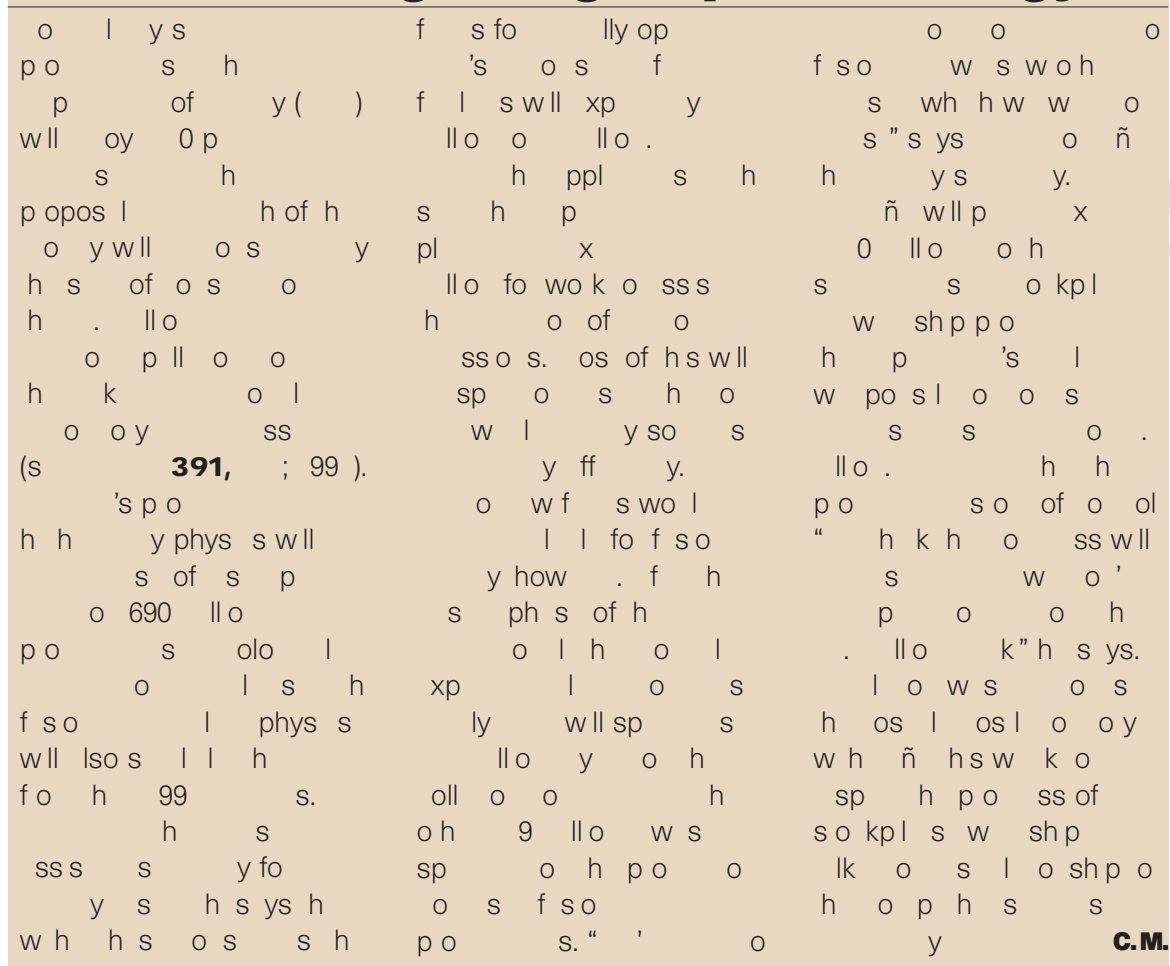

\section{NIH basks in broad support}

President Bill Clinton has asked Congress for the biggest dollar increase in the history of the National Institutes of Health (NIH) biomedical agency, with the focus on cancer research spending.

The request, made in the $\$ 1.73$ trillion 1999 budget Clinton sent to the Congress on Monday (2 February), for $\$ 1.15$ billion in new money would bring the NIH's budget to $\$ 14.8$ billion in 1999 - an 8.4 per cent increase. The budget also projects a 48 per cent increase in spending on NIH by the end of 2003 , when the agency's funding would reach $\$ 20.2$ billion.

Cancer research fared particularly well, with Vice President Al Gore using a White House ceremony last week to declare scientists "right on the verge" of a breakthrough, and to tout a 65 per cent, $\$ 4.7$ billion increase in cancer funding at NIH over the next five years. Ninety per cent of it would go to the National Cancer Institute (NCI).

In spite of this focus on cancer, "everyone is a winner in this budget", says NIH's director, Harold Varmus. "There is not a single activity at the NIH that is not going to be markedly enhanced."

Clinton calls the new money "vital" to America's continued leadership in science and technology, and describes NIH as the "flagship" of his 'Research Fund for America', a $\$ 25.3$ billion, five-year package of spending increases on science and technology, of which NIH would ultimately collect $\$ 17$ billion.

Like the rest of the fund, the NIH increases would be funded entirely from revenues from a proposed $\$ 368.5$ billion settlement with the tobacco industry, under which Congress would limit cigarette makers' liability. That settlement is, however, regarded as far from certain to be enacted by Congress.

Health and human services secretary Donna Shalala has insisted that, if the tobacco agreement collapses, the administration will find the NIH money elsewhere within its budget. "This is not contingency funding," she said at a briefing last week.

Congressional Republicans questioned that. Arlen Specter (Republican, Pennsylvania), who chairs the Senate subcommittee that funds the NIH, called the assumed tobacco revenues "pie in the sky" and questioned where the new money will come from.

Among NIH institutes, the National Human Genome Research Institute would benefit most handsomely, with a 10.3 per cent increase to $\$ 240$ million. The NCI would see its budget boosted by 8.9 per cent, to $\$ 2.8$ billion, in 1999.

Throughout NIH, research project grants would reach a record number of 28,603 . The number of new grants and grants competing for renewal would increase by 8.4 per cent, to 8,267 . The value of these new and competing grants would next year be boosted on a onetime basis by 10 per cent.

Separately, funds for NIH training grants would be boosted by 19 per cent, with most of the money going to stipends. Meredith Wadman

\section{EPA to spend more on clean air and water}

The $\$ 7.8$ billion budget request for the Environmental Protection Agency (EPA) is up 6 per cent from this year's level, with much of the increase going to pay for clean water and air programmes. But the agency's overall funding for science and technology goes down 6 per cent, to $\$ 631$ million, and the Office of Research and Development drops 9 per cent to $\$ 487$ million.

\section{S S wo $k$ oos
$\mathrm{s}$}

The US Geological Survey's \$807 million budget request represents a 6 per cent increase over last year's appropriation, but funding is projected to decline slightly, to $\$ 796$ million, by 2003. The 1999 increase includes money for clean water initiatives, species and habitat conservation studies, and $\$ 15$ million for a multi-agency natural disaster information network.

\section{Technology projects fall from presidential grace}

This Clinton budget is the first since 1993 to omit grandiose plans for two programmes that were once in the vanguard of the administration's technology policy. No expansion proposals are made for the Advanced Technology Program and the Manufacturing Extension Partnership, both run by the Department of Commerce. 